\title{
Uptake of purines in Plasmodium falciparum- infected human erythrocytes is mostly mediated by the human Equilibrative Nucleoside Transporter and the human Facilitative Nucleobase Transporter
}

\author{
Neils B Quashie ${ }^{1 *}$, Lisa C Ranford-Cartwright ${ }^{2}$, Harry P de Koning ${ }^{2}$ \\ From Parasite to Prevention: Advances in the understanding of malaria \\ Edinburgh, UK. 20-22 October 2010
}

\section{Background}

Plasmodium parasites are unable to synthesize purines de novo and have to salvage them from the host. Due to this limitation in the parasite, purine transporters have been an area of focus in the search for novel antimalarial drugs. Although the uptake of purines through the human equilibrative nucleoside transporter (hENT1), the human facilitative nucleobase transporter (hFNT1) and the parasite-induced new permeation pathway (NPP) has been studied, no information appears to exist on the relative contribution of these three transporters to the uptake of adenosine and hypoxanthine. Using the appropriate transporter inhibitors, the role of each of these salvage pathways to the overall purine transport in intraerythrocytic Plasmodium falciparum was systematically investigated.

\section{Methods}

The transport of adenosine, hypoxanthine and adenine into uninfected and P. falciparum-infected human erythrocytes was investigated in the presence or absence of classical inhibitors of the hFNT1, hENT1 and NPP such as NPPB, NBMPR and furosemide. The effective inhibition of the various transporters by the classical inhibitors was verified using appropriate known substrates. The ability of high concentration of unlabelled substrates to saturate these transporters was also studied.

${ }^{1}$ Centre for Tropical Clinical Pharmacology and Therapeutics, University of Ghana Medical School, Accra, Ghana

Full list of author information is available at the end of the article

\section{Results}

Transport of exogenous purine into infected or uninfected erythro-cytes occurred primarily through saturable transporters rather than through the NPP. Hypoxanthine and adenine appeared to enter erythrocytes mainly through the hFNT1 nucleobase transporter whereas adenosine entered predominantly through the hENT1 nucleoside transporter. The rate of purine uptake was approximately doubled in infected cells compared to uninfected erythrocytes. In addition, it was found that the rate of adenosine uptake was considerably higher than the rate of hypoxanthine uptake in infected human red blood cells (RBC). It was also demonstrated that furosemide inhibited the transport of purine bases through hFNT1.

\section{Conclusion}

Collectively, the data obtained in this study clearly show that the endogenous host erythrocyte transporters hENT1 and hFNT1, rather than the NPP, are the major route of entry of purine into parasitized RBC. Inhibitors of hENT1 and hFNT1, as well as the NPP, should be considered in the development of anti-malarials targeted to purine transport.

\section{Acknowledgement}

The work was financially supported with GETfund from the Ghanaian government and a Wellcome Trust Value in People Award

\section{Author details \\ 'Centre for Tropical Clinical Pharmacology and Therapeutics, University of Ghana Medical School, Accra, Ghana. ${ }^{2}$ Institute of Biomedical and Life}


Published: 16 December 2010

doi:10.1186/1475-2875-9-S2-P66

Cite this article as: Quashie et al:: Uptake of purines in Plasmodium

falciparum-infected human erythrocytes is mostly mediated by the

human Equilibrative Nucleoside Transporter and the human Facilitative

Nucleobase Transporter. Malaria Journal 2010 9(Suppl 2):P66.

Submit your next manuscript to BioMed Central and take full advantage of:

- Convenient online submission

- Thorough peer review

- No space constraints or color figure charges

- Immediate publication on acceptance

- Inclusion in PubMed, CAS, Scopus and Google Scholar

- Research which is freely available for redistribution

Submit your manuscript at www.biomedcentral.com/submit
C Biomed Central 